\title{
FRAGMENTARY REMAINS OF ODONTOCETES (CETACEA, MAMMALIA) FROM THE MIOCENE OF THE LOWER TAGUS BASIN (PORTUGAL)
}

Trabajo presentado a las XVIII Jornadas de Paleontología y

II Congreso Ibérico de Paleontología

Universidad de Salamanca

Salamanca, 24-29 de Septiembre de 2002

\author{
Mário ESTEVENS ${ }^{1,2}$ and Miguel Telles ANTUNES ${ }^{1,3}$ \\ ${ }^{1}$ Centro de Estudos Geológicos, Faculdade de Ciências e Tecnologia, Uni- \\ versidade Nova de Lisboa, Quinta da Torre, P-2829-516 Caparica, Portugal. \\ ${ }^{2}$ estevens@mail.fct.unl.pt \\ ${ }^{3} \mathrm{mta} @$ mail.fct.unl.pt
}

Estevens, M. and Antunes, M.T. 2004. Fragmentary remains of odontocetes (Cetacea, Mammalia) from the Miocene of the Lower Tagus Basin (Portugal). [Restos fragmentarios de odontocetos (Cetacea, Mammalia) del Mioceno de la Cuenca del Bajo Tajo (Portugal).] Revista Española de Paleontología, 19 (1), 93-108. ISSN 02136937.

\begin{abstract}
This first systematic account of the scarcely studied Miocene cetaceans from Portugal describes 17 previously unpublished odontocete specimens from the Lower Tagus Basin. In spite of their fragmentary nature, at least a familial assignment was accomplished for most, and some were even tentatively ascribed to known genera: the Physeteridae are represented only by isolated teeth of "Scaldicetus" type; the Platanistidae by a tympanic not definitely assigned to a particular genus; the Eurhinodelphinidae by a lumbar vertebra and an atlas, both only tentatively referred to this family; and the Kentriodontidae comprise the most diversified forms, including rostral and mandibular fragments of a kentriodontine close to Rudicetus, isolated teeth of another kentriodontine (cf. Macrokentriodon sp.), and rostral and mandibular fragments of an undetermined lophocetine. Some additional scrappy remains are listed only as Odontoceti indet.

This small sample includes forms known both from the eastern and western North Atlantic, and the Mediterranean, thus reasserting the importance of the geographic position of Portugal as a link between all of these regions. Further systematic research may precise with which of them the Lower Tagus Basin Miocene odontocete fauna has a closer relationship, although, based on this preliminary data, the greater similarity seems at present to be with the western North Atlantic.
\end{abstract}

Keywords: Cetacea, Odontoceti, Miocene, Portugal, paleobiogeographic correlations.

\section{RESUMEN}

En este primer apunte sistemático de los escasamente estudiados cetáceos miocenos de Portugal se describen 17 ejemplares inéditos de odontocetos, hallados en la Cuenca del Bajo Tajo. A pesar de su naturaleza fragmentaria, muchos han sido clasificados al menos a nivel familiar, y algunos incluso a nivel genérico: los Physeteridae están representados sólamente por dientes aislados de tipo "Scaldicetus"; los Platanistidae por un timpánico no atribuido a ningún género en particular; los Eurhinodelphinidae por una vértebra lumbar y un atlas, ambos sólo tentativamente atribuidos a esta familia; y los Kentriodontidae abarcan las formas más diversificadas, incluyendo fragmentos rostrales y mandibulares de un kentriodontino cercano a Rudicetus, dientes aislados de un otro kentriodontino (cf. Macrokentriodon sp.), y fragmentos rostrales y mandibulares de un lofocetino indeterminado. Algunos restos incompletos adicionales se describen sólamente como Odontoceti indet.

Esta pequeña muestra incluye formas conocidas en el Atlántico Norte (oriental y occidental) y Mediterráneo, reafirmando así la importancia de la situación geográfica de Portugal como un punto de conexión entre todas estas regiones. La continuación de la investigación sistemática podrá precisar con cuál de éstas presenta una mayor semejanza la fauna de odontocetos miocenos de la Cuenca del Bajo Tajo, aunque, basado en estos datos preliminares, actualmente parezca ser con la del Atlántico Norte occidental.

Palabras clave: Cetacea, Odontoceti, Mioceno, Portugal, correlaciones paleobiogeográficas. 


\section{INTRODUCTION}

Although long known, the Portuguese Miocene Cetacea have been scarcely studied in the past. Research on the whole of the Neogene marine mammals from Portugal was recently resumed at the "Centro de Estudos Geológicos, Faculdade de Ciências e Tecnologia, Universidade Nova de Lisboa" (Estevens, 1998, 2000). The present systematic account elaborates on a previous report on a small part of the Miocene cetacean fossils from Portugal (Estevens and Antunes, 2002), namely the unpublished odontocete material formerly gathered by one of us (M.T.A.).

The specimens in this collection (housed at the "Departamento de Ciências da Terra, Faculdade de Ciências e Tecnologia, Universidade Nova de Lisboa", Monte de Caparica, Portugal) were not catalogued. Hence, a provisional reference system was devised with the purpose of identifying the odontocete remains described in this study. Each specimen was assigned a different number, associating remains belonging to a same individual under a same number. These are preceded by the abbreviations MTA (Miguel Telles Antunes collection) and CO (Cetacea Odontoceti).

All specimens were collected from the distal part of the Lower Tagus Basin (LTB), namely from Lisbon Region (LR) and Setúbal Peninsula (SP) (Fig. 1). The Miocene series in this area, the most complete in Portugal, consists of several intercalated marine and continental units that span from 23 to $8.5 \mathrm{Ma}$ approximately (specimens described here range between 18.5 and 8.5 Ma). Due to their importance, these deposits have long been intensively studied. Cotter (1904) first defined a number of local lithostratigraphic units (LLU) that became of wide usage. Most recently, the application of sequential stratigraphy led to the recognition of 10 depositional sequences (DS), bounded by regional disconformities related to transgression surfaces (Antunes et al., 2000). The geographic and stratigraphic origin of each odontocete specimen within the LTB is specified in Table 1.

A total of 17 specimens (MTA-CO-2 to MTA-CO-18) are herein described. These are for the most part fragmen-

\begin{tabular}{|c|c|c|c|c|c|c|c|c|c|}
\hline Epoch & $\begin{array}{c}\text { Early } \\
\text { Miocene }\end{array}$ & \multicolumn{4}{|c|}{ Middle Miocene } & \multicolumn{3}{|c|}{ Late Miocene } & $\begin{array}{c}\text { Late } \\
\text { Miocene? }\end{array}$ \\
\hline Age & $\begin{array}{c}\text { middle } \\
\text { Burdigalian }\end{array}$ & $\begin{array}{c}\text { early } \\
\text { Serravallian }\end{array}$ & \multicolumn{3}{|c|}{ middle Serravallian } & \multicolumn{3}{|c|}{ middle Tortonian } & Tortonian? \\
\hline $\mathrm{Ma}$ & $18.5-18.0$ & $15.0-14.5$ & \multicolumn{3}{|c|}{$14.0-13.0$} & \multicolumn{3}{|c|}{$9.5-8.5 ?$} & $?$ \\
\hline DS & B1 & \multirow{2}{*}{\multicolumn{4}{|c|}{ S1 }} & \multirow{2}{*}{\multicolumn{3}{|c|}{$\begin{array}{l}\text { T2? } \\
\text { VIlb }\end{array}$}} & $\mathrm{T} 1$ or $\mathrm{T} 2 ?$ \\
\hline LLU & $\mathrm{IVa}$ & & & & & & & & VIla or VIIb? \\
\hline $\begin{array}{l}\text { Locality } \\
\text { (region) }\end{array}$ & $\begin{array}{c}1 \\
\text { Palença de } \\
\text { Baixo } \\
\text { (SP) }\end{array}$ & $\begin{array}{c}2 \\
\text { Brielas } \\
\text { (SP) }\end{array}$ & $\begin{array}{c}3 \\
\text { Costa de } \\
\text { Caparica } \\
\text { (SP) }\end{array}$ & $\begin{array}{c}4 \\
\text { Cerâmica } \\
\text { Dias Coelho } \\
(\mathrm{LR})\end{array}$ & $\begin{array}{c}5 \\
\text { Quinta do } \\
\text { Alfundăo } \\
(L R)\end{array}$ & $\begin{array}{c}6 \\
\text { Foz do Rego } \\
\text { (SP) }\end{array}$ & $\begin{array}{c}7 \\
\text { Fonte da } \\
\text { Telha } \\
\text { (SP) }\end{array}$ & $\begin{array}{l}8 \\
\text { Adiça } \\
\text { (SP) }\end{array}$ & $\begin{array}{l}\text { Unknown } \\
(?)\end{array}$ \\
\hline Taxa & & & & & & & & & \\
\hline $\begin{array}{l}\text { Physeteridae } \\
\text { "Scaldicetus" sp. ...... }\end{array}$ & & MTA-CO-10 & & & & & MTA-CO-13 & MTA-CO-18 & \\
\hline $\begin{array}{l}\text { Platanistidae } \\
\quad \text { Gen. and sp. indet. ... }\end{array}$ & & & & & & & & & MTA-CO-7 \\
\hline $\begin{array}{l}\text { ? Eurhinodelphinidae } \\
\text { Gen. and sp. indet. ... }\end{array}$ & MTA-CO-8 & & MTA-CO-9 & & & & & & \\
\hline $\begin{array}{l}\text { Kentriodontidae } \\
\text { cf. Rudicetus sp. ............ }\end{array}$ & & & & & $\begin{array}{c}\text { MTA-CO-2 } \\
+\end{array}$ & & & & \\
\hline cf. Macrokentriodon sp. ... & ……….... & ………..... & ………....... & ……..... & ……....... & $\begin{array}{l}\text { MTA-CO-11 } \\
\text { MTA-CO-12 }\end{array}$ & 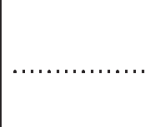 & $\begin{array}{l}\text { MTA-CO-15 } \\
\text { MTA-CO-16 } \\
\text { MTA-CO-17 }\end{array}$ & \\
\hline $\begin{array}{l}\text { Lophocetinae indet. ......... } \\
\text { Odontoceti indet. } \\
\text { Gen and so indet } 1\end{array}$ & ….............. & ........... & .................. & $\begin{array}{l}\text { MTA-CO-4 } \\
\text { MTA-CO-5 }\end{array}$ & & $\ldots \ldots \ldots \ldots \ldots$ & ........ & $\ldots \ldots \ldots \ldots$ & \\
\hline Gen. and sp. indet. 2 & & & & MTA-CO-6 & & & & & \\
\hline Gen. and sp. indet. 3 & & & & & & & & MTA-CO-14 & \\
\hline
\end{tabular}

Table 1. Taxonomic list of odontocetes from the Lower Tagus Basin Miocene in the Miguel Telles Antunes collection, with indication of geographic and stratigraphic origin of specimens. Ma. Million years ago. DS. Depositional sequences of Antunes et al. (2000). LLU. Local lithostratigraphic units of Cotter (1904). LR. Lisbon Region. SP. Setúbal Peninsula. 


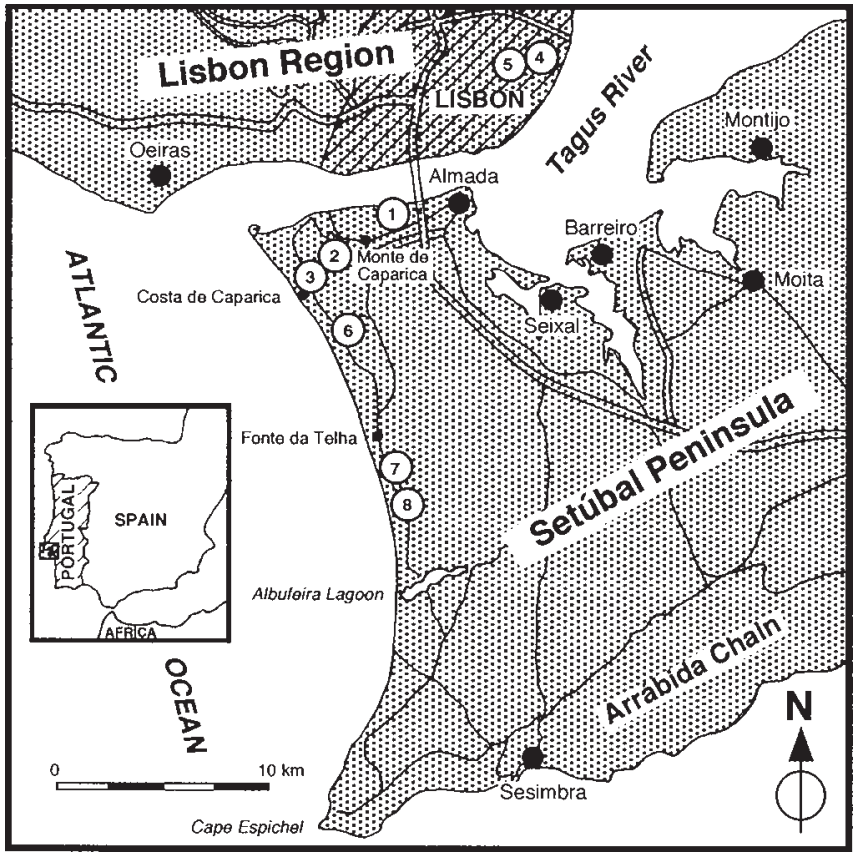

Figure 1. Geographic situation of odontocete localities within the distal part of the Lower Tagus Basin. 1. Palença de Baixo (SP). 2. Brielas (SP). 3. Costa de Caparica (SP). 4. Cerâmica Dias Coelho (LR). 5. Quinta do Alfundão (LR). 6. Foz do Rego (SP). 7. Fonte da Telha (SP). 8. Adiça (SP).

tary, and include rostral and mandibular portions, isolated teeth, one incomplete tympanic, one isolated atlas and one incomplete lumbar vertebra. Nevertheless, at least a familial assignment was accomplished for most specimens, and some were even tentatively ascribed to known genera. In total, 4 families of odontocetes and 9 different taxa (including 3 forms of uncertain familial affinities) are represented in this collection.

\section{SYSTEMATICS}

ORDER CETACEA Brisson, 1762 SUBORDER ODONTOCETI Flower, 1864

Superfamily Physeteroidea (Gray, 1821) Gill, 1872

Family Physeteridae Gray, 1821

Subfamily Hoplocetinae Cabrera, 1926

Genus Scaldicetus du Bus, 1867

$$
\text { "Scaldicetus" sp. }
$$

Fig. 2A-C

Referred specimens: MTA-CO-10, MTA-CO-13 and MTACO-18, all isolated teeth.

Description: MTA-CO-10: Enameled crown well preserved, but root otherwise severely damaged, lacking most of antero-lingual proximal half (Fig. 2A). Essentially conical crown curves slightly postero-lingually towards apex, and passes smoothly into root without any constriction. Finely wrinkled light brown enamel has straight basal margin, but no carinae nor wear facets. Thick cement layer of preserved portion of root badly fragmented. Still, root would probably be thicker approximately at mid-length (Table 2), and slightly labio-lingually compressed overall. Break at labial surface of cement layer allows to perceive existence of well-developed pulp cavity.

MTA-CO-13: Reduced to enameled crown and distalmost portion of root (Fig. 2B). Crown complete and, although larger (Table 2), rather similar to previous in shape. Enamel darker brown in color, much more coarsely wrinkled, and with irregular basal margin. No carinae, as in previous, but incipient vertical wear facet present at supposed postero-lingual surface. Preserved portion of root lost cement cover altogether and only dentine core remains. Largely open pulp cavity (14 mm wide) suggests that tooth may have belonged to young individual.

MTA-CO-18: Most complete tooth, nearly intact apart from physiological wear of crown (Fig. 2C). Large, inclined facet affects both the apex and almost the entire lingual surface (down to base without reaching the root though). Preserved portion conical, suggesting similar shape to that of previous teeth. Enamel layer broken on postero-lingual side, thus exposing dark dentine core. Remaining enamel pale gray in color and essentially smooth (possibly as a result of weathering, for some vestiges of rugosities still present). Root complete and rather large, constituting nearly $9 / 10$ of total preserved length of tooth (Table 2). Region immediately below crown slightly constricted, forming distinct neck. Below, root becomes much inflated at midlength and tapers again towards tip. Cement surface displays some short longitudinal grooves on labial side of distal half (at level of most expanded region), and an undulating dark band circling the entire perimeter.

Discussion: The large size, inflated roots, and proportionately small crowns readily identify these teeth as belonging to the sperm whale family. Within the Physeteridae, the additional presence of enamel restricts them to the subfamily Hoplocetinae (as defined by Muizon, 1991). Indeed, the rugose enameled conical crowns and large bulbous roots agree with the common conceptualization of the genus Scaldicetus du Bus, 1867. This poorly defined genus was originally based on isolated teeth, and few cranial remains assignable to this form have been subsequently described (Hirota and Barnes, 1994). Nevertheless, more than a dozen of nominal species, likewise based on isolated teeth, have been assigned to Scaldicetus worldwide (Varola et al., 1988; Kazár, 2002).

\begin{tabular}{l|c|c|c}
\hline \multicolumn{1}{c|}{ Measurements (in mm) } & MTA-CO-10 & MTA-CO-13 & MTA-CO-18 \\
\hline Greatest length as preserved & $72.5 \mathrm{i}$ & - & $107.8 \mathrm{i}$ \\
\hline Greatest height of crown & 18.9 & 26.2 & $13.0 \mathrm{i}$ \\
\hline Greatest diameter of crown & 11.1 & 17.0 & 14.0 \\
\hline Greatest length of root & $59.3 \mathrm{i}$ & - & 93.0 \\
\hline Greatest diameter of root & $21.0 \mathrm{i}$ & - & 32.6 \\
\hline
\end{tabular}

Table 2. Measurements of isolated teeth of "Scaldicetus" sp.; i - incomplete. 

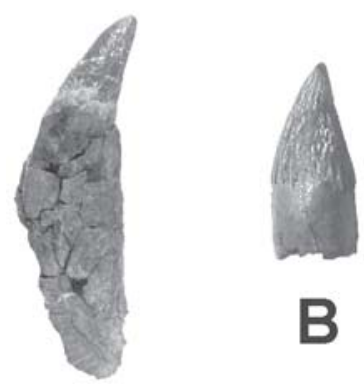

A
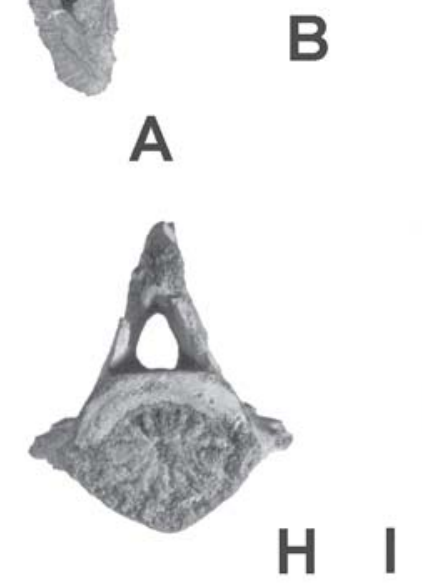

C
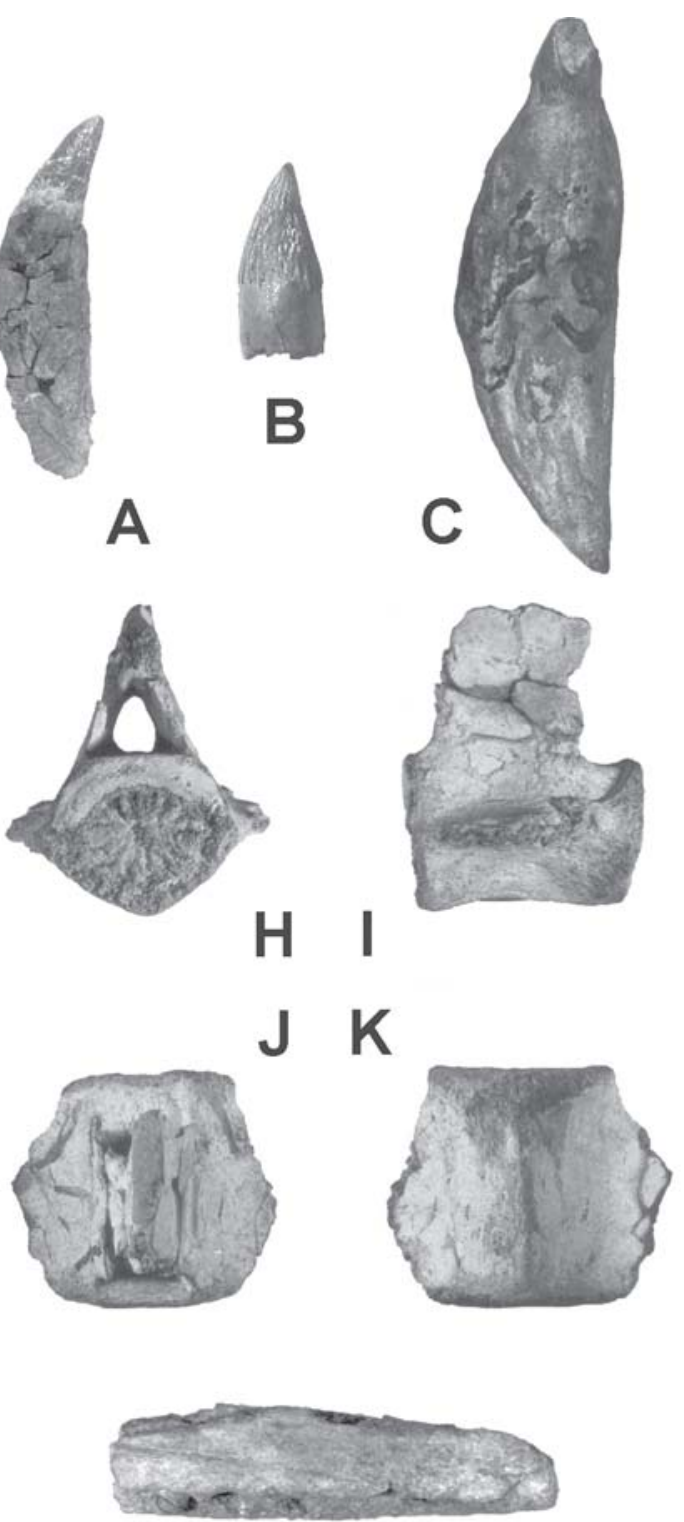

$\mathbf{P}$

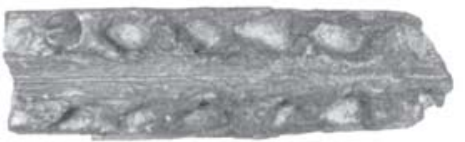

Q
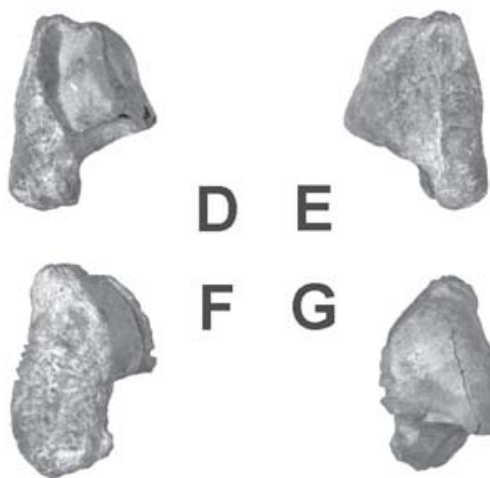

G
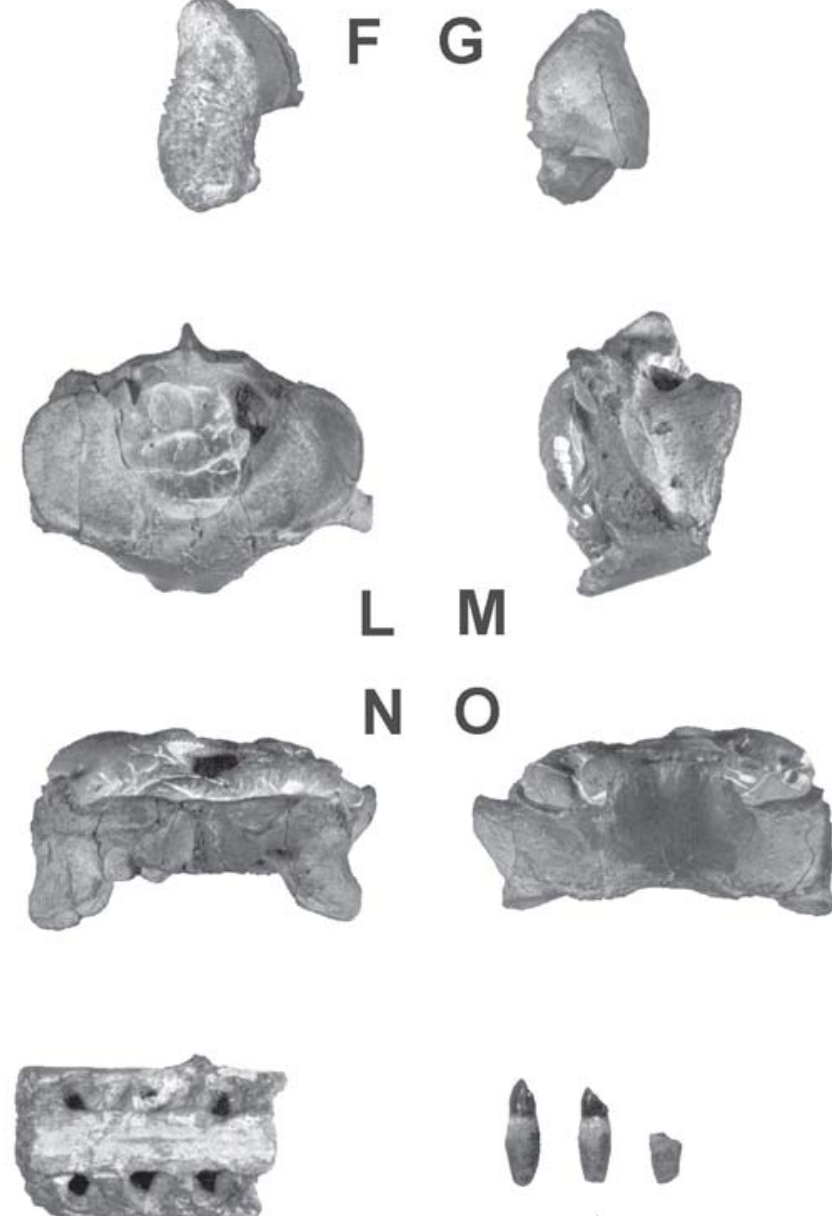

$\mathbf{R}$

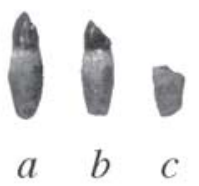

$\mathrm{T}$

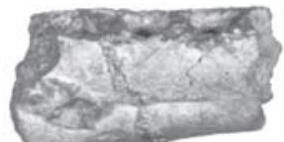

S

Figure 2. Specimens of Physeteridae, Platanistidae, ? Eurhinodelphinidae and Odontoceti indet. from the Lower Tagus Basin Miocene in the Miguel Telles Antunes collection. A-C. Isolated teeth of "Scaldicetus" sp. A. MTA-CO-10. B. MTA-CO-13. C. MTA-CO-18. D-G. Right tympanic MTA-CO-7 of Platanistidae indet. D. Dorsal view. E. Ventral view. F. Medial view. G. Lateral view. H-O. Isolated vertebrae of ? Eurhinodelphinidae indet. H-K. Anterior lumbar vertebra MTA-CO-8. H. Anterior view. I. Left lateral view. J. Dorsal view. K. Ventral view. L-O. Atlas MTA-CO-9. L. Anterior view. M. Right lateral view. N. Dorsal view. O. Ventral view. P-T. Remains of Odontoceti indet. P-Q. Distal rostrum fragment MTA-CO-5. P. Right lateral view. Q. Ventral view. R-S. Symphyseal mandible fragment MTA-CO-6. R. Dorsal view.

S. Right lateral view. T. Isolated teeth MTA-CO-14a-c. Scale bar $=5 \mathrm{~cm}$. 
Among these, MTA-CO-10 and MTA-CO-18 are compatible in size and general shape with $S$. grandis (du Bus, 1872) and S. mortselensis (du Bus, 1872), both originally described from Belgium. Abel (1905) distinguished between isolated teeth of these two similar-sized forms based solely on crown characters, such as roughness of enamel and presence/absence of carinae. However, Menesini and Tavani (1968) noted that these varied widely, and consequently regarded them as probably non-diagnostic. MTACO-13, on the other hand, seems closer to $S$. caretti du Bus, 1867 or S. degiorgii Varola, Landini and Pilleri, 1988, both characterized by notably larger size and rougher enamel. The latter could supposedly be further distinguished by the peculiar morphology of the root (Varola et al., 1988), but this is not preserved in the Portuguese tooth.

Still, as the taxonomy of Scaldicetus itself is presently far from settled (Morgan, 1994, and Hirota and Barnes, 1994, even suggest it may not be a natural grouping), only a provisional generic assignment is proposed for the Portuguese specimens. This assignment serves basically to indicate the presence of this widespread morphological type of physeterid teeth also in the Portuguese Miocene.

Superfamily Platanistoidea (Gray, 1863) Muizon, 1991 Family Platanistidae (Gray, 1863) Muizon, 1987

\section{Genus and species undetermined}

Fig. 2D-G

Referred specimen: MTA-CO-7, an incomplete right tympanic. Description: Lacks part of outer lip (namely dorsal margin and region posterior to lateral groove), posterior region of lateral lobe, and sigmoid and posterior processes. Anterior extremity also slightly eroded, but remains of wide-based projection indicate original presence of strong anterior spine. Latter separated from salient antero-lateral convexity by prominent notch. Outer lip bears oblique, inconspicuous lateral groove, affecting only dorsal half. Ventral groove wide and floored with spongy bone (but without protruding processes), running from posterior end to about $5 \mathrm{~mm}$ posteriorly to anterior preserved end (where separated from anterior spine by elevated convex area). Although missing posterior region of lateral lobe, ventral lobes would have been most certainly separated posteriorly by ventral groove and remarkably different in thickness (medial much thinner than lateral). Nothing can be said about their comparative length though (Table 3). Dorsal border of involucrum vaguely sigmoidal, resulting from shallow excavation of postero-lateral region anteriorly to non-preserved posterior process.

\begin{tabular}{l|c}
\hline \multicolumn{1}{c|}{ Measurements (in mm) } & MTA-CO-7 \\
\hline Length from anterior tip to posterior end of medial lobe & $40.0 \mathrm{i}$ \\
\hline Width at level of lateral groove & 28.0 \\
\hline
\end{tabular}

Table 3. Measurements of right tympanic of Platanistidae indet.; i - incomplete.
Discussion: The presence of a strong anterior spine on the tympanic (of which only vestiges are preserved in MTA$\mathrm{CO}-7)$ has been considered a synapomorphy of the group Platanistoidea + Eurhinodelphinoidea + Delphinida (Muizon, 1991). According to this author, such character shows a reversal tendency to reduction, or even loss, in the infraorder Delphinida. In the superfamily Eurhinodelphinoidea, it is also attenuated in comparison to the Platanistoidea. Only in the latter (and more specifically in the group Platanistidae + Squalodelphinidae) is the anterior spine separated from a salient antero-lateral convexity by such a prominent notch (Muizon, 1987). This character (regarded by the referred author as a synapomorphy of the Platanistidae + Squalodelphinidae) is well marked in MTA-CO7 , and allows to place the latter firmly in this group. The Portuguese tympanic may be further assigned to the Platanistidae (and not to the Squalodelphinidae) due to the presence of the following synapomorphies pointed out for the former by Muizon (1987): reduction in transverse thickness of medial lobe, greater elevation of lateral wall, and ventral groove ending before anterior extremity.

A generic assignment of MTA-CO-7 to any of the Miocene forms included in the family (Zarhachis Cope, 1868 and Pomatodelphis Allen, 1921) is more difficult to establish due to its incomplete condition. Although morphologically very close to both (compare particularly with the Pomatodelphis tympanic figured in Hulbert et al., 2001: fig. 17.8C-D), direct comparisons with a significant sample of tympanics of these two genera revealed that the Portuguese specimen differs consistently from both forms. Namely, it shows a wider and shallower ventral groove (without diagonal elevation at mid-length), a more elevated lateral wall, and a slightly more sigmoidal ventral border of involucrum. It otherwise seems intermediate between the two in a few other characters (some of which may share with one or the other): thickness of medial lobe, development of lateral furrow, and development of notch separating the anterior spine from the antero-lateral convexity.

Thus, MTA-CO-7 cannot be definitely assigned to either of these genera and will be herein designated only as an undetermined genus and species of Platanistidae.

\section{? Superfamily Eurhinodelphinoidea (Abel, 1901) Muizon, 1988}

? Family Eurhinodelphinidae (Abel, 1901) Muizon, 1991

\section{Genus and species undetermined}

Fig. $2 \mathrm{H}-\mathrm{O}$

Referred specimens: MTA-CO-8, an anterior lumbar vertebra; and MTA-CO-9, an isolated atlas.

Description: MTA-CO-8: Nearly complete centrum and not so complete neural arch (Figs. 2H-K). Lacks most of both epiphyses (except for dorsal margin of anterior one), both transverse 


\begin{tabular}{l|c}
\hline \multicolumn{1}{c|}{ Measurements (in mm) } & MTA-CO-8 \\
\hline Greatest height of vertebra as preserved & $62.3 \mathrm{i}$ \\
\hline Greatest height of centrum & 34.7 \\
\hline Greatest width of centrum & 39.5 \\
\hline Greatest length of centrum & $49.1 \mathrm{i}$ \\
\hline Least length of pedicles of neural arch & $30.0 \mathrm{e}$ \\
\hline Width of transverse processes at base & 35.0 \\
\hline
\end{tabular}

Table 4. Measurements of anterior lumbar vertebra of ? Eurhinodelphinidae indet.; i - incomplete, e - estimated.

processes, pre- and post-zygapophyses, and majority of neural spine. Centrum longer than broad, wider than high (Table 4), and clearly pentagonal in cross section. Dorsal surface medially depressed and lateral surfaces markedly concave both above and below transverse processes. Sharp, well-developed median keel runs full length of ventral surface of centrum, curving concavely from end to end. On the contrary, neural arch occupies only about $2 / 3$ of total length on dorsal surface. Although incomplete, arch seems to have inclined somewhat anteriorly and to have had slightly concave anterior and posterior margins of pedicles. Neural canal shaped as almost perfect isosceles triangle, only slightly wider $(18.0 \mathrm{~mm})$ than high $(17.4 \mathrm{~mm})$. Although broken off near base, still possible to observe that transverse processes were rather thin and narrower than centrum (to which they attached at mid-height and anteriorly dislocated).

MTA-CO-9: Small (Table 5) and nearly complete, except for missing left dorsal and right ventral transverse processes (Figs. 2L-O). Most of posterior surface and entire neural canal still covered or filled with sediment. Anterior articular facets crescent-shaped (broader above than below), and deeply concave. Dorso-lateral edges project strongly anteriorly, while ventral margins are separated by interval of $14.5 \mathrm{~mm}$ and merge almost imperceptibly with antero-ventral surface of centrum. Neural arch not much elevated, bearing thin, well developed (although incomplete) neural spine. Foramina for passage of intervertebral artery anteriorly dislocated, opening directly into neural canal (constituting large grooves on both antero-lateral bases of arch). Latter not pierced thus, and longer medially $(14.8 \mathrm{~mm})$ than laterally $(10.2 \mathrm{~mm})$. Dorsal and ventral transverse processes approximately of same size, although differing somewhat in shape. Preserved right dorsal process tabular and curved, pro-

\begin{tabular}{l|c}
\hline \multicolumn{1}{c|}{ Measurements (in mm) } & MTA-CO-9 \\
\hline Greatest height of right anterior articular facet & 30.8 \\
\hline Greatest width of right anterior articular facet & 27.0 \\
\hline Greatest length of neural arch & 14.8 \\
\hline Greatest length of ventral arch & 28.0 \\
\hline Greatest height of vertebra & 58.4 \\
\hline Greatest width of vertebra & $78.5 \mathrm{e}$ \\
\hline Height of neural canal anteriorly & 33.6 \\
\hline Width of neural canal anteriorly & 33.4 \\
\hline Greatest width of anterior articular surface & 69.3 \\
\hline Greatest width of posterior articular surface & 62.3 \\
\hline
\end{tabular}

Table 5. Measurements of isolated atlas of ? Eurhinodelphinidae indet.; e - estimated. jecting essentially dorso-posteriorly and very little laterally. Inversely, preserved left ventral process rather conical, short and stout, projecting ventro-posteriorly. Bases of dorsal and ventral processes connected by diagonal ridges on both lateral surfaces of centrum. Hypapophysial process rather large, broad, and dorso-ventrally flattened, clearly projecting postero-ventrally. Medial carina on dorsal surface confers three-pointed outline to posterior margin. Entire articular facet for odontoid process of axis and most of posterior articular facets still covered with sediment. Still, exposed ventro-lateral margins of latter distinctly set off from posterior face of centrum.

Discussion: The taxonomic assignment of isolated vertebrae is usually problematic.

In the case of MTA-CO-8, the incompleteness of the specimen makes its determination even more difficult. Still, comparison of this vertebra with other lumbars figured in the literature reveals the existence of a strong morphological similarity of the well-preserved centrum and neural canal with some specimens commonly attributed to members of the Eurhinodelphinoidea (sensu Muizon, 1988a). Among these, the Portuguese vertebra resembles most closely the lumbars of Eurhinodelphis du Bus, 1867 figured either by Kellogg (1925: pl. 8, figs. 45; pl. 9, figs. 4-6) or Abel (1931: pl. XXII, figs. 2-4; pl. XXV, figs. 10-13; pl. XXVI, figs. 1-4). All of these share a pronounced median keel on the ventral surface of centrum, a strikingly proportionate triangular-shaped neural canal, and, most notably, a distinctly pentagonal outline of centrum in cross section. The comparatively smaller size of MTA-CO-8, on the other hand, may derive from the fact that this belonged to a young individual (as seems to be suggested by the unfused epiphyses).

Unlike the lumbar vertebra, the MTA-CO-9 atlas is nearly complete, thus allowing a more thorough appreciation of its characters. Most of these may indeed be considered plesiomorphic, and while certainly uncharacteristic of the more derived Delphinoidea, seem otherwise typical of such primitive groups as the Platanistoidea, Eurhinodelphinoidea, or even the Inioidea (Muizon, 1984, 1988b). Among these, the Portuguese atlas is comparatively more derived than the former (notably in the thinner centrum and smaller transverse processes), and contrarily more primitive than the latter (thicker centrum and greater development both of transverse processes and of groove for intervertebral artery). Still, its general morphology and dimensions are somewhat reminiscent of the few known atlases of Pontoporiidae (included in the Inioidea), and indeed this vertebra was previously suggested to belong in this essentially South American family (Estevens and Antunes, 2002). The overall morphology is considerably more archaic though, and seems instead more compatible with the intermediate structure described for the Eurhinodelphinidae. Although members of this family display a wide array of atlases' shapes (Abel, 1931; Myrick, 1979), MTA-CO-9 resembles notably some speci- 
mens formerly attributed to them, namely those figured by Abel (1931: pl. XIX, figs. 2-6), Okazaki (1976: pl. 10, figs. 3a-b), Myrick (1979: pls. 11, 13, 44 and 45) and Fordyce (1983: fig. 1J). Most of these vertebrae also have well-excavated articular facets, well-developed transverse processes, and similarly shaped neural canals, although some (but not all) may be significantly larger and thicker than the Portuguese atlas.

The low diagnostic value of such post-cranial elements does not allow for a more detailed determination though, for which, based on morphological similarity alone, only a conservative, and yet tentative, familial assignment is suggested for the two Portuguese vertebrae.

\section{Superfamily Delphinoidea (Gray, 1821) Flower, 1864 Family Kentriodontidae (Slijper, 1936) Barnes, 1978 Subfamily Kentriodontinae Slijper, 1936 Genus Rudicetus Bianucci, 2001}

\section{cf. Rudicetus sp.}

Fig. 3A-H

Referred specimens: MTA-CO-3, a proximal rostrum fragment; and MTA-CO-2, which includes a distal rostrum fragment $(a)$, a post-symphyseal fragment of right dentary with an attached tooth $(b)$ and a symphyseal mandible fragment $(c)$. Although labeled as collected from different localities, the two rostral fragments obviously belong to the same individual.

Description: MTA-CO-3: Broken off posteriorly to posteriormost alveoli proximally, and approximately at level of $10^{\text {th }}$ alveoli distally (Figs. 3A-B). Premaxillae smoothly convex at proximal region, becoming progressively flatter distally. Medial borders nowhere complete throughout entire length of fragment, thus exposing rather deep mesorostral gutter. Where most complete though (at proximal end) only $9 \mathrm{~mm}$ apart, thus suggesting that gutter may have been almost completely roofed over in this region originally. Floor of mesorostral gutter almost entirely constituted by maxillae, except at distal end where vomer protrudes inbetween. Maxillae rather convex, thick and with rounded lateral margins posteriorly to tooth rows, becoming increasingly flatter and steeper towards distal end (where nearly vertical). Ventral surface of maxillae medially convex and laterally concave posteriorly to tooth rows, becoming increasingly flatter distally. Thin lamina of vomer (maximum width of $5 \mathrm{~mm}$ ) appears medially at level of $5^{\text {th }}$ alveoli. Alveolar rows face clearly ventro-laterally and follow lateral margins of palate throughout their length. At least 10 rounded alveoli preserved on left maxillary (although only vestiges of distalmost) and 11 on right (Table 6). All bear remains of broken teeth, except for empty posteriormost pair (smaller, shallower than rest, and slightly dislocated medially).

MTA-CO-2a: Clearly the continuation of MTA-CO-3 (Figs. $3 \mathrm{C}-\mathrm{D})$, which resembles in many characters. Premaxillae rather incomplete at proximal region, but better preserved distal portion indicates that these bones would have been rather high, nearly vertical, and approximately $10 \mathrm{~mm}$ apart when complete. Completely exposed floor of mesorostral gutter almost entirely constituted by maxillae, except for narrow strip of vomer at proximal region. Maxillae continue tendency observed in proximal fragment, with flat lateral surfaces progressing from nearly to completely vertical towards distal end (where become essentially parallel and as narrow as premaxillae). Distally fused premaxillae and maxillae separated by increasingly fainter, anteriorly inclined sulcus at both lateral surfaces of rostrum. Nonpreserved apex would thus be formed exclusively by premaxillae in original condition. Maxillae on palatal surface medially separated by deep groove that becomes progressively attenuated towards distal end. Proximal $50 \mathrm{~mm}$ of groove occupied by thin lamina of vomer (maximum width of $3 \mathrm{~mm}$ at proximal end). Total of 14 alveoli preserved on each side, with remains of teeth only on 5 left posteriormost (plus another one at middle of fragment) and 2 right posteriormost. When added to maximum number of alveoli preserved in proximal fragment, this figure indicates a total rostral count well over 25. Proximal alveoli similar in size and shape to those in proximal fragment, but distal ones get somewhat larger and more closely spaced as a result of increasingly thinner septa (Table 6).

\begin{tabular}{l|c|c}
\hline \multicolumn{1}{c|}{ Measurements (in mm) } & MTA-CO-3 & MTA-CO-2a \\
\hline Total length as preserved & 125.7 & 140.4 \\
\hline Width at proximal end & 83.8 & 36.8 \\
\hline Height at proximal end & 42.6 & $22.2 \mathrm{i}$ \\
\hline Width at distal end & 45.4 & 22.8 \\
\hline Height at distal end & 29.0 & $21.5 \mathrm{i}$ \\
\hline Anteroposterior diameter of alveoli & 5.2 & $6.0-7.1$ \\
\hline Transverse diameter of alveoli & 5.0 & $5.0-7.0$ \\
\hline
\end{tabular}

Table 6. Measurements of rostral fragments of cf. Rudicetus sp.; i - incomplete.

MTA-CO-2b: Still preserves 9 closely spaced rounded alveoli in quite short length (Table 7), thus suggesting a considerable total number of post-symphyseal teeth (Figs. 3E-F). Alveolar row runs diagonally from near lateral margin distally (where faces slightly laterally), to near medial margin proximally (where faces noticeably medially). Middle alveolus bears nearly complete tooth (described in detail below). No special features observed on smoothly convex lateral surface, but medial surface displays well-marked groove at about $1 / 3$ of dentary height below alveolar row. Groove becomes increasingly larger proximally, eventually affecting whole height of dentary and

\begin{tabular}{l|c|c}
\hline \multicolumn{1}{c|}{ Measurements (in mm) } & MTA-CO-2b & MTA-CO-2c \\
\hline Total length as preserved & 75.7 & 95.4 \\
\hline Width at proximal end & $13.5 \mathrm{i}$ & 36.5 \\
\hline Height at proximal end & 33.0 & 27.3 \\
\hline Width at distal end & 14.2 & 23.0 \\
\hline Height at distal end & 26.2 & 21.5 \\
\hline Anteroposterior diameter of alveoli & 5.8 & 6.2 \\
\hline Transverse diameter of alveoli & 5.5 & 5.4 \\
\hline
\end{tabular}

Table 7. Measurements of mandibular fragments of cf. Rudicetus sp.; i - incomplete. 


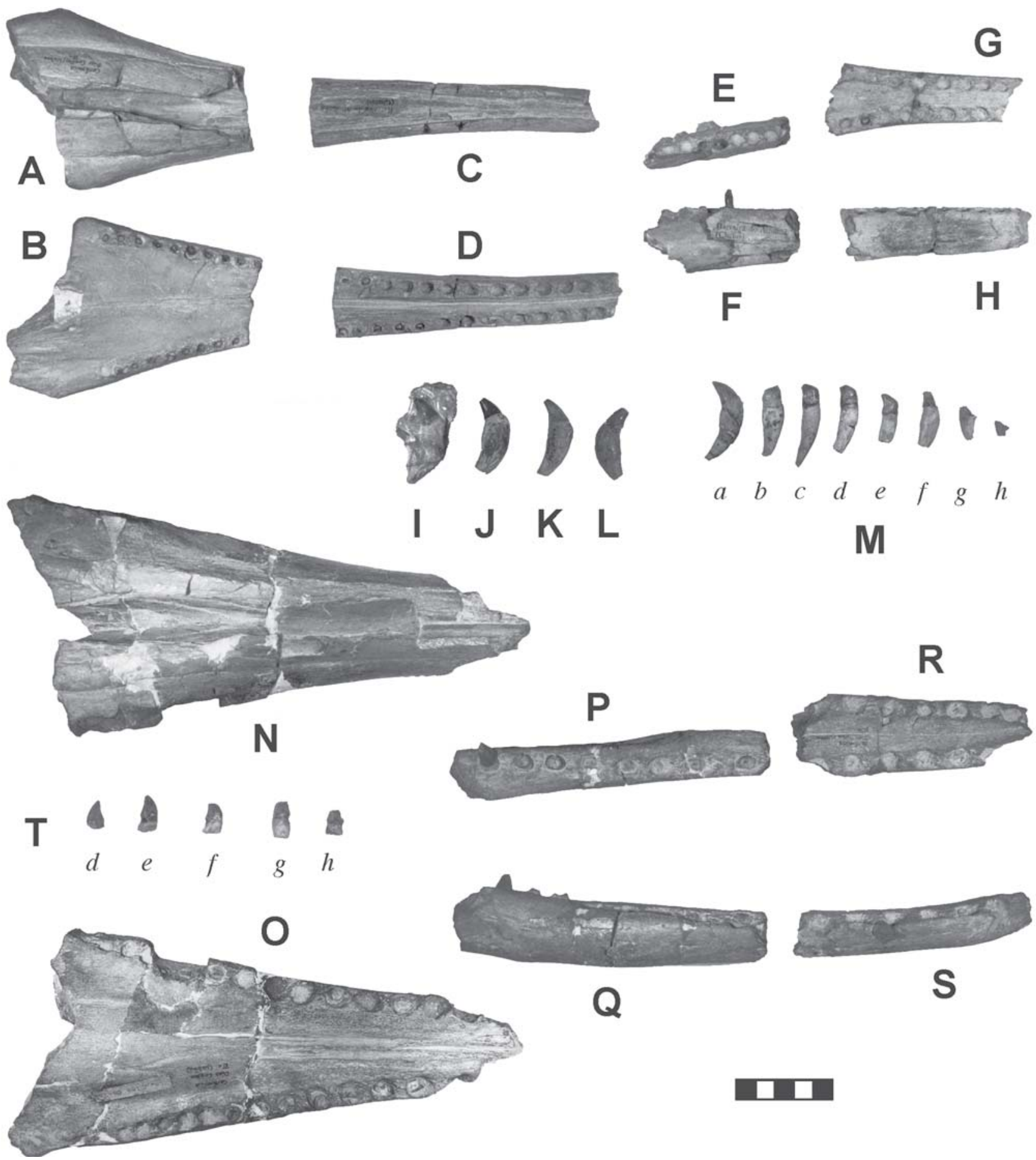

Figure 3. Specimens of Kentriodontidae from the Lower Tagus Basin Miocene in the Miguel Telles Antunes collection. A-H. Remains of cf. Rudicetus sp. A-B. Proximal rostrum fragment MTA-CO-3. A. Dorsal view. B. Ventral view. C-D. Distal rostrum fragment MTA-CO-2a. C. Dorsal view. D. Ventral view. E-F. Right dentary fragment MTA-CO-2b. E. Dorsal view. F. Right lateral view. G-H. Symphyseal mandible fragment MTA-CO-2c. G. Dorsal view. H. Right lateral view. I-M. Isolated teeth of cf. Macrokentriodon sp. I. MTA-CO-11. J. MTA-CO-12. K. MTA-CO-16. L. MTA-CO-17. M. MTA-CO-15a- $h$. N-T. Remains of Lophocetinae indet. N-O. Rostrum fragment MTA-CO-4a. N. Dorsal view. O. Ventral view. P-Q. Right dentary fragment MTA-CO-4b. P. Dorsal view. Q. Right lateral view. R-S. Symphyseal mandible fragment MTA-CO-4c. R. Dorsal view. S. Right lateral view. T. Detached teeth MTA-CO- $4 d-h$. Scale bar $=5 \mathrm{~cm}$. 
conferring strongly concave aspect to medial surface. Ventral border regularly convex throughout.

MTA-CO-2c: Dentaries firmly ankylosed and triangular in cross section (Figs. 3G-H). Dorsally rounded symphyseal angle preserved at proximal end. A total of 10 rounded alveoli preserved on right dentary and 9 on left (indicating a total mandibular count well over 19 when added to number of alveoli preserved in post-symphyseal fragment). Diameter and mediolateral inclination of alveoli roughly constant (Table 7). Anteroposterior inclination and spacing, however, vary throughout fragment; from nearly vertical and farther apart at level of symphyseal angle, to increasingly more inclined and closer spaced distally. Longitudinal shallow depression between tooth rows shows fine (almost indistinguishable) median line separating dentaries. Nearly flat, ventro-medially inclined lateral surfaces perforated by two small foramina each. Dentaries on convex ventral surface of symphysis also separated by median groove, which becomes progressively attenuated distally.

Single preserved tooth: Presently glued to middle alveolus of MTA-CO-2 $b$ (Figs. 3E-F), but apparently rotated to some degree from original position. Conical crown nearly straight except for apicalmost region (only missing tip), which curves slightly towards anterior end (lingual side originally?). Smooth dark brown enamel has straight base all around circular basal section. Surfaces presently facing medially and laterally marked by wear facets. Former with smooth edges, affecting only apical half; latter well-marked, affecting apical 2/3. Short exposed portion of root slightly thicker than crown (Table 8), but likewise circular in section.

Discussion: A combination of characters such as a widebased, slender rostrum with slightly concave lateral margins and distally fused maxillae and premaxillae, coupled with a long mandibular symphysis with triangular-sectioned, ankylosed dentaries, allows to safely refer these remains to the Kentriodontidae. The affinities of the Portuguese fragments within this family must be looked up among a few small to medium-sized forms characterized both by intermediate rostrum length and distally unroofed mesorostral gutter.

The pithanodelphine Atocetus Muizon, 1988, and particularly the incertae sedis Leptodelphis Kirpichnikov, 1954, resemble somewhat the Portuguese remains in general morphology. However, they are both smaller and differ also in a few characters (specially the former). The latter is more similar, but the holotype and single known specimen is so poorly preserved and figured that no detailed comparisons are possible at this moment.

\begin{tabular}{l|c}
\hline \multicolumn{1}{c|}{$\begin{array}{c}\text { Measurements } \\
\text { (in mm) }\end{array}$} & $\begin{array}{c}\text { Tooth at } \\
\text { MTA-CO-2b }\end{array}$ \\
\hline Greatest height of crown & $7.3 \mathrm{i}$ \\
\hline Greatest diameter of crown & 4.0 \\
\hline Length of root exposed above alveolus & 3.0 \\
\hline Greatest diameter of root & 4.8 \\
\hline
\end{tabular}

Table 8. Measurements of tooth attached to right dentary fragment of cf. Rudicetus sp.; i - incomplete.
The Portuguese fragments are instead closer to some kentriodontines, namely Kentriodon Kellogg, 1927 and Rudicetus Bianucci, 2001. Within the former, they are most similar to K. pernix Kellogg, 1927, from which differ, however, in considerably larger size, probably fewer teeth, and anterior margin of palatines not reaching the level of posteriormost alveoli. The greatest similarity is thus with Rudicetus squalodontoides (Capellini, 1878), a species long known from Italy and recently redescribed by Bianucci (2001) as a kentriodontid. The Portuguese form agrees closely with this species in most characters, namely general size, proportions and shape of rostrum, location of premaxillary foramina posteriorly to rostrum base, shape and diameter of alveoli, and maybe number of teeth. The only apparent difference regards the morphology of the single preserved post-symphyseal tooth. This is straighter and lacks the denticles described for the most anterior of the two maxillary teeth known for $R$. squalodontoides (see Bianucci, 2001). However, according to the same author Rudicetus may have exhibited slight heterodonty, for which these differences are not granted too much meaning (the few teeth known for the two specimens come from non-comparable positions in the dental series).

In conclusion, although slightly younger than the late Burdigalian referred specimen from Italy, the Portuguese remains may thus be designated as cf. Rudicetus sp.

\section{Genus Macrokentriodon Dawson, 1996}

\section{cf. Macrokentriodon sp.}

Fig. 3I-M

Referred specimens: MTA-CO-11, MTA-CO-12, MTA-CO-16 and MTA-CO-17, all single isolated teeth; and MTA-CO-15, comprising eight associated teeth $(a-h)$.

Description: MTA-CO-11: Still partially encased in matrix, lingual side only exposed (Fig. 3I). Fairly complete, except for apex of crown and proximal region of root. Apart from some slight differences, very similar to detached MTA-CO-12 in morphology and size (Table 9), for which see more detailed description of latter below. Differences limited to less evident bulge at distal anterior margin of root (possibly due to partial encasement), and absence, as far as visible, of additional grooves at proximal half of root. Proximal labio-lingual medial constriction of root, however, lightly outlined at broken end. Pulp cavity completely closed.

MTA-CO-12: Crown apex worn and proximal tip of root broken (Fig. 3J). Tooth noticeably arched in labial or lingual view, slightly concave posteriorly and markedly convex anteriorly. Crown noticeably curved lingually, with oval basal section, and covered by finely rugose dark brown enamel (indistinct longitudinal anastomosing ridges). Both anterior and posterior vestigial carinae better marked at apical portion and gradually fainter towards base. Crown merges imperceptibly with root without any constriction or neck below straight enamel base. Contrarily, bulge at antero-lingual distal region of root results 


\begin{tabular}{l|c|c|c|c}
\hline \multirow{2}{*}{$\begin{array}{c}\text { Measurements } \\
\text { (in mm) }\end{array}$} & \multicolumn{4}{|c}{ MTA-CO- } \\
\cline { 2 - 5 } & 11 & $\mathbf{1 2}$ & $\mathbf{1 6}$ & $\mathbf{1 7}$ \\
\hline Greatest length as preserved & $46.0 \mathrm{i}$ & $43.2 \mathrm{i}$ & $43.6 \mathrm{i}$ & $40.7 \mathrm{i}$ \\
\hline Greatest height of crown & $14.0 \mathrm{i}$ & $13.6 \mathrm{i}$ & $14.3 \mathrm{i}$ & $11.5 \mathrm{i}$ \\
\hline Greatest diameter of crown & $10.0 \mathrm{i}$ & 10.3 & 11.7 & 9.8 \\
\hline Greatest length of root & $37.0 \mathrm{i}$ & $35.0 \mathrm{i}$ & $34.0 \mathrm{i}$ & $32.9 \mathrm{i}$ \\
\hline Greatest diameter of root & 14.0 & 15.3 & 14.0 & 14.4 \\
\hline
\end{tabular}

Table 9. Measurements of single isolated teeth of cf. Macrokentriodon sp.; i - incomplete.

in distinct step at anterior margin immediately below crown. Below, root becomes gradually thinner (Table 9) and more labiolingually compressed towards proximal broken end (where oval section becomes also somewhat labio-lingually strangled medially). Cement carved with several longitudinal grooves on proximal half, better marked at postero-lingual side. Pulp cavity virtually closed (less than $0.5 \mathrm{~mm}$ in diameter).

MTA-CO-16: Nearly complete, again except for worn apex of crown and broken proximal end of root (Fig. 3K). General shape and size similar to previous teeth (Table 9). Marked lingual curvature of crown and gentle labial curvature of root results in slight sigmoidal shape of tooth as a whole in anterior or posterior view (somewhat more noticeable than in previous teeth). Light brown, straight-based and essentially smooth enamel shows only a few longitudinal striae at basal region. Poorly defined carina present at anterior surface, but not at posterior. Bulge at antero-lingual distal region of root less pronounced, as well as overall thinner, more labio-lingually compressed root. Pulp cavity very small (less than $1 \mathrm{~mm}$ in diameter).

MTA-CO-17: Comparatively more eroded than any of previous teeth (Fig. 3L), but otherwise rather similar both in size (Table 9) and shape (particularly to MTA-CO-12). Differences may result essentially from weathering and/or older age of present tooth, namely more transversely worn crown, presence of distinct neck immediately below crown (resulting from weathering of cement in distal region of root), and completely closed pulp cavity. Also, vestigial carina present only at posterior surface of crown and root overall thicker and more rounded in section (in spite of largely weathered cement). As a result, bulge at antero-lingual distal region of root not quite so obvious.

MTA-CO-15: Comprises eight associated teeth that differ somewhat among themselves in size (Table 10) and morphology (Fig. 3M), thus suggesting slight heterodonty of individual.

Tooth $a$ : Closely similar to isolated teeth described above (particularly MTA-CO-16), and almost complete (except for proximal tip of root). Crown labio-lingually compressed and noticeably curved postero-lingually towards apex. Light brown enamel appears smooth to naked eye, but finely rugose under magnification (due to presence of indistinct longitudinal anastomosing striae, slightly more developed at postero-lingual basal surface). Faint vertical carinae present both at anterior and posterior sides, affecting only apical $2 / 3$. Root noticeably bent posteriorly and weakly so labially, resulting in gentle sigmoidal shape of tooth as a whole (specially in posterior view). Smaller bulge at antero-lingual distal region of root, which seems overall thinner and more labio-lingually compressed (even medially strangled at proximal end). Pulp cavity completely closed.
Tooth $b$ : Rather different from any previously described teeth, apart from similar dimensions and ornamentation of enamel. Crown lacks apical region, but preserved portion apparently straighter and noticeably thicker with strong lingual swelling approximately $4 \mathrm{~mm}$ above base. Excavation on basal posterior surface could correspond to wear facet, but no traces of carinae. Root nearly straight (except at proximal region, which curves gently postero-lingually) and more labio-lingually compressed than in $a$ (becoming gradually so towards proximal end). In fact, greatest labio-lingual diameter of crown larger than equivalent diameter of root. Distal region of root slightly constricted antero-posteriorly immediately below crown. Proximal half run by some ill-defined longitudinal grooves, especially at antero-labial surface. Pulp cavity closed.

Teeth $c-e$ : Very similar among themselves, but clearly distinct from any other teeth. Crown similarly broken in $c$ and $d$, but complete in $e$. All noticeably compressed antero-posteriorly with apical regions markedly bent to lingual side forming distinct angle at labial margin. Basal enamel margin more irregularly curved than on previous teeth (apically convex at posterolabial side). Ornamentation of light brown enamel similar to that of $a$ and $b$, although slightly more developed (specially at lingual surface and particularly in $e$ ). Narrow, inclined wear facets at postero-lingual surfaces of $c$ and $d$ originate small excavation at level of swelling, but better preserved crown of $e$ has short vertical carina (not reaching apex nor base) at exact same position. This could be original condition in this type of teeth (or in teeth occupying this position in dental series) and excavations would then result from wear. Tooth $d$ shows additional poorly defined facet at base of anterior surface. Roots similarly shaped, but only $c$ has complete one. Latter nearly straight at distal half (where all three weakly compressed antero-posteriorly and as thick as base of crowns), but markedly bent posteriorly at proximal portion (which becomes increasingly more tapered and antero-posteriorly flattened).

Tooth $f$ : Even more incomplete than previous, apparently representing yet another morphological type in this assemblage. Lacks apical region of crown and proximal region of root, which makes orientation of tooth rather arbitrary. Preserved portion of crown indicates that may have curved gently either posteriorly, lingually, or even both. Anterior (or labial) surface diagonally cut by wear facet. Surface opposite to slightly concave one also worn by vertical facet (though less prominent). Ornamentation of light brown enamel almost invisible (even under magnification), for which may be considered essentially smooth. Basal margin of enamel undulates slightly around tooth. Root noticeably compressed perpendicularly to curvature of crown and most

\begin{tabular}{l|c|c|c|c|c|c}
\hline \multirow{2}{*}{$\begin{array}{c}\text { Measurements } \\
\text { (in mm) }\end{array}$} & \multicolumn{6}{|c}{ MTA-CO-15 } \\
\cline { 2 - 7 } & $\boldsymbol{a}$ & $\boldsymbol{b}$ & $\boldsymbol{c}$ & $\boldsymbol{d}$ & $\mathbf{e}$ & $\boldsymbol{f}$ \\
\hline Greatest length as preserved & $45.4 \mathrm{i}$ & $46.5 \mathrm{i}$ & $41.0 \mathrm{i}$ & $38.8 \mathrm{i}$ & $27.6 \mathrm{i}$ & $31.9 \mathrm{i}$ \\
\hline Greatest height of crown & 14.2 & $10.5 \mathrm{i}$ & $7.6 \mathrm{i}$ & $10.3 \mathrm{i}$ & 10.5 & $7.6 \mathrm{i}$ \\
\hline Greatest diameter of crown & 10.3 & 9.9 & 10.7 & 10.0 & 8.8 & 6.7 \\
\hline Greatest length of root & $39.6 \mathrm{i}$ & 40.0 & $34.3 \mathrm{i}$ & $32.5 \mathrm{i}$ & $19.5 \mathrm{i}$ & $26.0 \mathrm{i}$ \\
\hline Greatest diameter of root & 13.3 & 10.2 & 12.5 & 10.4 & 9.0 & 11.1 \\
\hline
\end{tabular}

Table 10. Measurements of more complete teeth $(a-f)$ in MTA-CO-15 assemblage of cf. Macrokentriodon sp.; i - incomplete. 
expanded approximately at mid-length. Curves gently either posteriorly or lingually towards proximal end (where slightly strangled medially). Pulp cavity closed.

Teeth $g-h$ : Reduced to small proximal fragments of root with completely closed pulp cavities. Both distinctly curved and noticeably compressed perpendicularly to curvature, with $g$ tapering more rapidly towards tip than $h$.

Discussion: Although the assignment of isolated teeth to a particular taxon is usually tentative, the sheer dimensions of the Portuguese specimens restrict their possible affinities to a few large-sized forms previously described in the literature. Most of these, however, constitute poorly defined taxa based merely on isolated teeth (or teeth attached to rostral and mandibular fragments not associated to significant cranial material) with a long and confusing systematic history.

Within the North Atlantic alone, some of these include the mandible and rostral fragments from Sort (France), on which Champsodelphis was based (see Muizon, 1988a), and the associated portion of rostrum and mandibles from the Bone Valley Formation (Florida, USA), which Morgan (1994) recently regarded as belonging to a large undetermined odontocete (possibly a platanistid). Teeth in these two forms are apparently quite similar to the Portuguese specimens, but, as referred above, they belong to poorly diagnosed taxa to which no further specimens should be assigned.

On the other hand, Dawson (1996a) recently described a new genus and species of a large kentriodontine (Macrokentriodon morani) based on a rather complete skull with 12 associated teeth from the Choptank Formation in Calvert County (Maryland, USA). These teeth show some variation in size and morphology, which Dawson (1996a) thought to be an indication of slight heterodonty. The Portuguese specimens are very alike the sample of $M$. morani teeth represented in her fig. 4 both in general size and shape, but also, and more significantly, in the mesio-distal variation. The single isolated teeth MTA-CO-11, MTA-CO-12, MTA-CO-16 and MTA-CO-17, in particular, are most similar to the larger teeth figured in the upper row (corresponding to the anterior portion of the dental series). The MTA-CO-15 assemblage, on the other hand, resembles remarkably the known set of teeth of $M$. morani in their mesio-distal variation. Like the previous, tooth $a$ is very similar to the anterior teeth figured in the upper row, for which it must have likewise occupied a similar position. Teeth $c-e$ are instead most similar (although slightly larger) to the two posterior teeth represented at the lower right angle of the same figure. Like these, the Portuguese specimens have a pronounced curvature of the proximal region of root (preserved in $c$ ), and a lingual swelling at the base of crown (observed in all). The remaining teeth ( $b$ and $f$ ) have no correspondent among the figured teeth of $M$. morani and may have oc- cupied intermediate positions in the dental series (not preserved among the assemblage from the Choptank Formation).

In spite of a slight difference in age (late Middle Miocene for the holotype of $M$. morani and early Late Miocene for the Portuguese teeth), the latter may thus be still tentatively assigned to cf. Macrokentriodon sp.

\section{Subfamily Lophocetinae Barnes, 1978}

\section{Genus and species undetermined \\ Fig. 3N-T}

Referred specimen: MTA-CO-4, comprising a rostrum fragment $(a)$, a right dentary fragment with an attached tooth $(b)$, a distal portion of mandibular symphysis $(c)$, and five detached teeth $(d-h)$.

Description: MTA-CO-4a: Largest and most important fragment within this assemblage (Figs. $3 \mathrm{~N}-\mathrm{O}$ ). Maxillae fairly complete throughout, except for eroded proximo-lateral margins on both sides. Proximal dorsal surfaces essentially flat to slightly concave, particularly on more complete left side. Two anteroposteriorly elongated foramina open close to suture with premaxilla and a nearly circular third one lies further postero-laterally on left maxilla. No sign of equivalent foramina at same level on less complete right maxilla. Horizontal medial surfaces extend anteriorly for about half-length of fragment, separated from progressively steeper lateral surfaces by medially converging edges. Premaxillae not as well preserved, exposing quite deep and wide mesorostral gutter at proximal half $(25 \mathrm{~mm}$ maximum). At distal half, where more complete, broken portion of left premaxilla artificially dislocated to mid-line covering gutter. Medial margins of premaxillae nowhere complete presently, but originally may have approached each other medially to roof gutter over (at least distally). As preserved, flatter proximally (where only slightly convex and barely elevated above maxillae), becoming increasingly more convex and vertical distally. Proximal lateral surfaces separated from apparently flatter and depressed medial region by poorly preserved anteriorly converging grooves. Lateral margins slightly constricted transversely at level of maxillary foramina (poorly marked on left side, but better defined on right). Lateral profile of rostrum curves gently dorsally towards distal end. Palatal surface constituted mostly by maxillae, which change from strongly convex medially and only slightly concave laterally at proximal region to increasingly flatter distally. From level of $8^{\text {th }}-9^{\text {th }}$ alveoli onwards, two large grooves ( $5 \mathrm{~mm}$ at widest point) appear in middle region separating increasingly more convex lateral surfaces from median maxillary ridge (initially blunt and nearly $10 \mathrm{~mm}$ wide, becoming progressively narrower and sharper distally). At level of $13^{\text {th }}-14^{\text {th }}$ alveoli, maxillae spread apart and ridge is replaced by median groove affecting intervening strip of premaxillae. Latter attains nearly $10 \mathrm{~mm}$ in width at distalmost preserved end (suggesting that rostrum apex would be constituted exclusively by premaxillae originally). In total, 15 rounded alveoli preserved on each maxilla (plus vestiges of 2 more at distalmost end of right one). Anteroposterior diameter of both alveoli and interalveolar septa increase steadily from posterior to anteriormost (Table 11). Some root fragments still 
preserved, namely 7 on left maxilla $\left(8^{\text {th }}\right.$ to $\left.14^{\text {th }}\right)$ and 5 on right $\left(5^{\text {th }}\right.$ to $7^{\text {th }}, 11^{\text {th }}$ and $\left.13^{\text {th }}\right)$.

MTA-CO-4b: Medial surface clearly rugose at distal $60 \mathrm{~mm}$ of fragment (corresponding to broken ankylosed symphysis) and increasingly smoother and more concave towards proximal end (corresponding to free ramus). Dentaries came together at an estimated angle of $24^{\circ}$ (Figs. 3P-Q). Median dorsal surface at symphyseal region essentially flat and higher than dorso-laterally facing alveolar row. Lateral surface steeply inclined ventromedially from lateral border of alveolar row at symphyseal region, becoming progressively attenuated proximally (smoothly convex at proximal end). Ventral border consequently quite sharp at symphyseal region, but smoothly rounded proximally. Dorsal surface dominated by alveolar row, of which 9 alveoli preserved (3 in symphyseal portion, 6 in free ramus). All bear remains of roots, but only second posteriormost alveolus still presents imperfectly preserved tooth crown (described in detail below). Alveoli gradually turn from adjacent to lateral border and facing notably laterally, at symphysis, to near medial border and facing clearly medially, at proximal end. Anteroposterior diameter of alveoli and of most intermediate septa varies little throughout preserved length (Table 11). Exceptions are abnormally long septum between anteriormost and preceding alveolus $(\approx 12 \mathrm{~mm})$ and, conversely, rather thin septum between two posteriormost alveoli $(\approx 3 \mathrm{~mm})$.

MTA-CO- $4 c$ : Rather robust, somewhat dorso-ventrally flattened and with firmly ankylosed dentaries (Figs. 3R-S). Vestiges of 6 rounded alveoli preserved on right dentary and 7 on left (all empty). Diameter and spacing between alveoli vary little throughout posteriormost six alveoli (Table 11). Left anteriormost alveolus, however, slightly medially dislocated and separated from precedent by much thinner septum (possibly indicating proximity to apex of mandible). Median dorsal surface essentially flat and higher than dorso-laterally facing alveolar rows, displaying also median narrow groove separating dentaries. Height of latter constant for most of length of fragment, whose distal end curves somewhat dorsally. Ventral surface also run from end to end by distinct median groove and additionally perforated by several pairs of foramina with associated grooves extending distally.

Detached teeth $d$-h: Although root proportions agree with fragments preserved in rostrum and mandible portions, no certain fit was possible with any preserved alveoli. Crown proportions also agree with those of single attached tooth (Table 12),

\begin{tabular}{l|c|c|c}
\hline \multicolumn{1}{c|}{$\begin{array}{c}\text { Measurements } \\
\text { (in mm) }\end{array}$} & \multicolumn{3}{c}{ MTA-CO-4 } \\
\cline { 2 - 4 } & $\mathbf{a}$ & $\boldsymbol{b}$ & $\mathbf{c}$ \\
\hline Total length as preserved & 287.0 & 171.7 & 131.8 \\
\hline Width at proximal end & $118.7 \mathrm{i}$ & 24.8 & 45.6 \\
\hline Height at proximal end & 46.0 & 37.0 & 26.0 \\
\hline Width at distal end & 56.2 & $52.0 \mathrm{e}$ & 36.6 \\
\hline Height at distal end & 37.8 & 33.4 & 24.5 \\
\hline Anteroposterior diameter of alveoli & $7.5-14.1$ & $12.0-13.3$ & $10.3-12.6$ \\
\hline Transverse diameter of alveoli & $7.5-13.7$ & $10.0-12.8$ & $9.4-11.6$ \\
\hline Length of interalveolar septa & $2.4-7.4$ & $5.0-6.0$ & $4.0-8.3$ \\
\hline
\end{tabular}

Table 11. Measurements of rostrum $(a)$ and mandibular fragments $(b-c)$ of Lophocetinae indet.; i - incomplete, e - estimated.

\begin{tabular}{l|c|c|c|c|c|c}
\hline \multirow{2}{*}{$\begin{array}{c}\text { Measurements } \\
\text { (in mm) }\end{array}$} & \multicolumn{7}{|c}{ MTA-CO-4 } \\
\cline { 2 - 7 } & $\boldsymbol{c}$ & $\boldsymbol{d}$ & $\boldsymbol{e}$ & $\boldsymbol{f}$ & $\boldsymbol{g}$ & $\boldsymbol{h}$ \\
\hline Length of root above alveolus & 6.0 & - & - & - & - & - \\
\hline Greatest height of crown & $11.0 \mathrm{i}$ & 15.0 & 13.0 & $9.8 \mathrm{i}$ & $9.7 \mathrm{i}$ & $8.7 \mathrm{i}$ \\
\hline Greatest diameter of crown & 9.3 & 9.5 & 9.7 & $9.5 \mathrm{i}$ & 10.3 & 9.3 \\
\hline Greatest diameter of root & 10.8 & - & 10.8 & 10.8 & 11.8 & $10.0 \mathrm{i}$ \\
\hline
\end{tabular}

Table 12. Measurements of attached $(c)$ and detached $(d-h)$ teeth of Lophocetinae indet.; i - incomplete.

thus confirming association of detached teeth with rest of assemblage. Slight differences in morphology suggest some degree of heterodonty (Fig. 3T).

Tooth $d$ : Reduced to nearly complete, well-preserved crown, which curves postero-lingually towards apex and has oval basal section (slightly constricted antero-posteriorly). Enamel coarsely rugose all over, although slightly more so at lingual surface below curved apex. Rugosities consist of longitudinal anastomosing ridges originating approximately $1 \mathrm{~mm}$ above enamel base (where coarsest) and becoming gradually finer towards apex (thus leaving essentially smooth band all around base). Well-defined vertical carinae extend from apex to about $2 \mathrm{~mm}$ above base, both at anterior and posterior surfaces. Posterior better marked and distinctly crenulated, specially in basal part; anterior slightly fainter, not crenulated and with narrow lingual wear facet adjacent to basal half. Basal margin of enamel irregularly curved (higher at labial surface and lower at anterior and posterior margins).

Teeth $e$-f: Very similar to each other. Crown of $e$ nearly complete, that of $f$ with broken apex. Both generally similar to $d$, but with some differences presumably related to a more posterior position in dental series. Crowns likewise bulbous and postero-lingually curved with slight antero-posterior constriction at base. Ornamentation of enamel also similar, but without carinae. Otherwise, both teeth display narrow vertical wear facets at postero-labial surfaces and more or less worn antero-lingual surfaces (only apical region in $e$, but almost whole height of crown in f). Basal margin of enamel likewise irregularly undulated, curving noticeably apically at antero-labial surfaces. Preserved small distal portions of roots suggest gentle posterior inclination. Constriction at crown base also affects distal region of roots, which become slightly thicker antero-posteriorly and labio-lingually compressed just below that. Pulp cavity open in $e$ and completely closed in $f$.

Teeth $g$ - $h$ : Very similar among themselves and slightly different from rest (resemble mostly single attached tooth, for which they too may have occupied posterior positions in dental series). Both lack apical and anterior regions of crowns, with $h$ somewhat more incomplete. Consequently, both appear overall straighter and more labio-lingually compressed than remaining teeth. Tooth $g$ has narrow vertical wear facet at posterior surface, while $h$ shows larger inclined one at postero-lingual surface. Antero-posterior constriction of crown base and distal region of root better marked than in previous teeth. Preserved portions of roots nearly straight and even more noticeably compressed labio-lingually. Pulp cavity completely closed in $g$, still open in $h$.

Attached tooth: Located at second posteriormost preserved alveolus of right dentary fragment MTA-CO-4b (Figs. 3P-Q). 
Crown noticeably inclined medially and poorly preserved (apical region broken and most of surface worn down to dentine core). Only anterior and posterior basal angles retain outer surface of enamel, which in this region seems smooth. Nevertheless, some rugosities still preserved in dentine surface reminiscent of ornamentation observed in detached teeth. Inclined, flat posterior surface may correspond to wear facet similar to one found in $h$.

Discussion: A similar combination of rostral and mandibular characters as those described above for MTA-CO-2 + MTA-CO-3 likewise allows to refer MTA-CO-4 to the Kentriodontidae. The latter specimen, however, seems more closely related to some larger, more robust forms, most of which are presently included in the subfamily Lophocetinae (Dawson, 1996b). Only the holotype is known for most of these, for which the generic affinities of the Portuguese remains may be tentatively found by direct comparison with each of these specimens.

Overall, MTA-CO-4a is quite similar to the incomplete rostrum of the holotype skull of Lophocetus calvertensis (Harlan, 1842) Cope, 1868, as figured by Eastman (1907). The Portuguese form is slightly larger though, and differs further in having comparatively narrower premaxillae at proximal region and lesser anterior extension of palatines and pterygoid sinuses (which do not reach the level of posteriormost alveoli).

A closer agreement, both in size and morphology, exists with the holotype and single specimen so far known of Liolithax pappus (Kellogg, 1955) Barnes, 1978. The Portuguese specimen differs from this form, however, in having the median ventral ridge of rostrum formed exclusively by the maxillae (instead of the vomer) and wider spaced alveoli both at rostrum and post-symphyseal portion of mandible (suggesting a probable lower tooth count overall). Some differences in tooth ornamentation are also apparent. Enamel rugosities extend nearly to the whole crown in the Portuguese teeth, while those of L. pappus are, supposedly, essentially smooth (Kellogg, 1955). The latter are somewhat rugose only at the inner surface of crown above the base (Barnes, 1978), which is also the region where the Portuguese teeth are more rugose. However, the holotype teeth of L. pappus are worn to varying degrees, and this could obscure the enamel ornamentation in a similar way to what happened with the tooth attached to MTA-CO- $4 c$.

Comparable elements of Hadrodelphis calvertense Kellogg, 1966 and MTA-CO-4 (such as rostrum, mandible and teeth) are also very similar among themselves (see Dawson, 1996b). Differences concern mainly tooth count and morphology. Although incomplete, the Portuguese mandible appears to have had more symphyseal teeth than that of $H$. calvertense. Posterior teeth of the latter possess also some mesio-labial crenulations (variable among specimens), which are lacking on any of the Portuguese teeth.
Additionally, and perhaps more significantly, MTA-CO-4 is much smaller than any specimen included in $\mathrm{H}$. calvertense. As the latter is distinguished from other Miocene odontocetes based primarily on its large size (Dawson, 1996b), the Portuguese remains cannot be reasonably assigned to this form. Note, however, that Morgan (1994) and Hulbert et al. (2001: fig. 17.7D) referred some isolated teeth from Florida to this genus, which not only resemble closely the Portuguese teeth, but are also smaller than the specimens from the Calvert.

In conclusion, differences between the Portuguese specimen and the forms referred above are slight, and MTA-CO-4 surely belongs in the Lophocetinae. Among these, the Portuguese form particularly resembles Liolithax and Hadrodelphis, both of which it shares some characters with. Due to the incompleteness of the specimen, a definite generic assignment is not possible though, for which only a conservative subfamilial placement is here retained.

\section{Odontoceti indet.}

Fig. 2P-T

Referred specimens: MTA-CO-5, a distal rostrum fragment; MTA-CO-6, a symphyseal mandible fragment; and MTA-CO-14, comprising three isolated teeth $(a-c)$.

Description: MTA-CO-5: Dorsal and left ventral surfaces badly eroded (Figs. 2P-Q). Most of premaxillae gone, leaving mesorostral gutter broadly exposed. When complete, however, premaxillae may have approached each other medially, at least partially roofing gutter over. Anteriorly inclined faint sulci separates premaxillae from maxillae on lateral surfaces (better preserved on right side). This suggests that apex of rostrum would be constituted exclusively by former. Seven antero-laterally facing alveoli present on each maxillary (although only anterior margins of posteriormost pair preserved). Single root preserved on second posteriormost right alveolus (Table 13).

MTA-CO-6: Dentaries firmly ankylosed and roughly triangular in cross section (Figs. 2R-S). Three pairs of empty alveoli completely preserved, plus vestiges of two other pairs at either end of fragment. Alveoli nearly circular in shape, rather deep,

\begin{tabular}{l|c|c}
\hline \multicolumn{1}{c|}{ Measurements (in mm) } & MTA-CO-5 & MTA-CO-6 \\
\hline Total length as preserved & 87.6 & 53.6 \\
\hline Width at proximal end & $25.4 \mathrm{i}$ & 29.3 \\
\hline Height at proximal end & $25.0 \mathrm{i}$ & 25.6 \\
\hline Width at distal end & 23.4 & 28.0 \\
\hline Height at distal end & $16.0 \mathrm{i}$ & 23.6 \\
\hline Anteroposterior diameter of alveoli & 8.0 & 7.0 \\
\hline Transverse diameter of alveoli & 6.8 & 5.7 \\
\hline Anteroposterior diameter of preserved tooth & 6.4 & - \\
\hline Transverse diameter of preserved tooth & 6.0 & - \\
\hline
\end{tabular}

Table 13. Measurements of rostrum fragment (MTA-CO-5) and mandible fragment (MTA-CO-6) of Odontoceti indet.; i - incomplete. 
facing slightly antero-laterally (Table 13). Area between tooth rows longitudinally depressed, presenting very fine median suture between dentaries. Short grooves associated to foramina (not reaching distal end of fragment) present on both ventromedially inclined lateral surfaces. Transversely convex ventral surface medially run by groove marking suture between dentaries.

MTA-CO-14: Comprises three small isolated teeth, none of which complete (Fig. 2T). First two have obliquely broken crowns and lack proximal tips of roots $(a-b)$, third reduced to small root fragment $(c)$. Preserved portions of crowns slightly compressed labio-lingually, curving gently postero-lingually towards apex. Base slightly constricted antero-posteriorly, for which greatest diameter not at this level, but slightly above it (Table 14). Both covered by essentially smooth light brown enamel, except for some poorly defined longitudinal grooves on slightly concave lingual surface. Both have also wear facets on labial surfaces, more deeply excavated in $a$ (where basal surface of crown and distal surface of root affected) and less marked in $b$ (where only limit between enameled crown and root affected). Base slightly undulated, higher at anterior and posterior sides and lower at lingual and labial sides. Roots gently curved lingually and nearly circular in section, attaining greatest diameter approximately $5 \mathrm{~mm}$ below base of crown $(a-b)$. Distal postero-labial side of otherwise regularly curving roots presents slight bulge in same teeth. Pulp cavity completely closed at broken proximal extremities of all three teeth, but small opening present at distal broken end of root fragment $c$.

\begin{tabular}{l|c|c|c}
\hline \multirow{2}{*}{$\begin{array}{c}\text { Measurements } \\
\text { (in mm) }\end{array}$} & \multicolumn{3}{c}{ MTA-CO-14 } \\
\cline { 2 - 4 } & $\mathbf{a}$ & $\boldsymbol{b}$ & $\boldsymbol{c}$ \\
\hline Greatest length as preserved & $23.0 \mathrm{i}$ & $21.0 \mathrm{i}$ & - \\
\hline Greatest height of crown & $7.8 \mathrm{i}$ & $6.4 \mathrm{i}$ & - \\
\hline Greatest diameter of crown & 5.5 & 5.7 & - \\
\hline Greatest length of root & $16.0 \mathrm{i}$ & $16.0 \mathrm{i}$ & - \\
\hline Greatest diameter of root & 7.7 & 7.4 & 7.4 \\
\hline
\end{tabular}

Table 14. Measurements of isolated teeth of Odontoceti indet.; i - incomplete.

Discussion: Remains this incomplete are very difficult to place taxonomically. The general morphology of the rostrum and mandible fragments are rather similar to the correspondent portions in MTA-CO-3 + MTA-CO-2, namely in such features as the rostrum apex contituted exclusively by premaxillae, the distally uncovered mesorostral gutter, and the supposedly long, firmly ankylosed and triangular cross-sectioned mandibular symphysis. All these characters are compatible with rostra and mandibles of Delphinoidea in general, and Kentriodontidae in particular. The rather simple, smooth-enameled teeth also agree with those of most Delphinoidea. Nevertheless, all these specimens are too incomplete to satisfactorily define an odontocete and thus are only listed as Odontoceti indet.

\section{CONCLUSIONS}

Based on this small and fragmentary sample, some preliminary paleobiogeographic correlations may be already attempted at this stage. Namely, some comparisons may be established with other Miocene odontocete faunas, mostly from the western and eastern North Atlantic and the Mediterranean.

As usual, the Physeteridae are represented only by Middle to Late Miocene isolated teeth, herein provisionally assigned to "Scaldicetus" sp. Isolated teeth of this illdefined (and probably just form) genus have been likewise recorded from correlative deposits worldwide (Kazár, 2002), for which its presence is not very significant from a paleobiogeographic point of view.

The Platanistidae are represented by an undetermined form, possibly of Late Miocene age. Traditionally, Miocene platanistids were known essentially from the North Atlantic realm, mostly from the Middle Atlantic Coastal Plain and Florida, USA (Gottfried et al., 1994; Morgan, 1994), but also from the Loire Basin, France (Muizon, 1987). However, they were recently reported also from the Mediterranean at Baltringen, Germany (Bianucci and Landini, 2002). The Portuguese record further confirms the presence of this family in the eastern North Atlantic.

The single Early and the Middle Miocene tentative records of ? Eurhinodelphinidae indet. are in agreement with other contemporaneous assemblages where the eurhinodelphinids predominate, such as the Calvert Formation, USA (Gottfried et al., 1994), the Antwerp Sands, Belgium (Abel, 1905), and the Belluno Sandstones and Pietra leccese, both in Italy (Bianucci and Landini, 2002).

Unsurprisingly, due to the predominant Middle to early Late Miocene age of the prospected deposits, the Kentriodontidae comprehend the most diversified forms. Within the North Atlantic, Macrokentriodon and the Lophocetinae were unquestionably known only from the western margin (Middle Atlantic Coastal Plain and Florida, USA) (Gottfried et al., 1994; Morgan, 1994; Dawson, 1996a). The undetermined lophocetine herein described, in particular, unequivocally registers the presence of this subfamily in Europe (contra Dawson, 1996b). Rudicetus, on the other hand, was previously known only from the Mediterranean (Italy) (Bianucci, 2001). These new reports further enlarge the traditionally scarce published record of the Kentriodontidae in the northeastern Atlantic (Ichishima et al., 1994).

Some additional Middle to early Late Miocene scrappy remains, listed only as Odontoceti indet., add no relevant information.

In conclusion, this sample includes forms widespread both in the North Atlantic and Mediterranean, others known primarily from both North Atlantic margins, and yet others previously recorded almost exclusively from the 
western margin. These are supplemented by an hitherto exclusively Mediterranean form. This diversity of correlations reasserts the importance of the geographic position of Portugal as a link between all of these regions. Further systematic research may precise with which of them the Lower Tagus Basin Miocene odontocete fauna has a closer relationship, although the greater similarity seems at present to be with the western North Atlantic.

\section{ACKNOWLEDGEMENTS}

M. Estevens benefited first from an "Initiation to Scientific Research" scholarship (BIC 2760) and later from a PhD scholarship (BD 21741), both granted by the "Fundação para a Ciência e a Tecnologia" under the PRAXIS XXI Program. Visits by the same author to the "Muséum National d'Histoire Naturelle" (MNHN), in Paris, and the "Institut Royal des Sciences Naturelles de Belgique" (IRScNB), in Brussels, were funded by a "Training and Mobility of Researchers" scholarship of the PARSYST Program (for the former in 2000) and by the PhD scholarship BD 21741 (for both in 2002). Special thanks are due to Christian de Muizon (MNHN) and Olivier Lambert (IRScNB) for helpful discussions during the stay at these institutions. M.T. Antunes participation is framed within the project "POCTI/36531/PAL/2000 - Studies on Portuguese Paleontology (Post-Paleozoic)", funded by the "Fundação para a Ciência e a Tecnologia / Ministério da Ciência e das Universidades". Giovanni Bianucci (Dipartimento di Scienze della Terra, Università di Pisa) and Jorge Morales (Museo Nacional de Ciencias Naturales, Madrid) provided useful revisions of the original manuscript.

\section{REFERENCES}

Abel, O., 1905. Les Odontocètes du Boldérien (Miocène supérieur) des environs d'Anvers. Mémoires du Musée Royal d'Histoire Naturelle de Belgique, 1, 1-95.

Abel, O., 1931. Das Skellet der Eurhinodelphiden aus dem oberen Miozän von Antwerpen. III. Teil und schluss der «Dauphins longirostres du Boldérien (Miocène supérieur) des environs d'Anvers». Mémoires du Musée Royal d'Histoire Naturelle de Belgique, 48, 191-334.

Antunes, M.T., Legoinha, P., Cunha, P.P. and Pais, J., 2000. High resolution stratigraphy and Miocene facies correlation in Lisbon and Setúbal Peninsula (Lower Tagus Basin, Portugal). Ciências da Terra (UNL), 14, 183-190.

Barnes, L.G., 1978. A review of Lophocetus and Liolithax and their relationships to the delphinoid family Kentriodontidae (Cetacea: Odontoceti). Natural History Museum of Los Angeles County Science Bulletin, 28, 1-35.

Bianucci, G., 2001. A new genus of kentriodontid (Cetacea: Odontoceti) from the Miocene of South Italy. Journal of Vertebrate Paleontology, 21, 573-577.

Bianucci, G. and Landini, W., 2002. Change in diversity, ecological significance and biogeographical relationships of the Mediterranean Miocene toothed whale fauna. Geobios, 35 (Mémoire spécial 24), 19-28.

Cotter, J.C.B., 1904. Esquisse du Miocène marin portugais. In: Mollusques tertiaires du Portugal (G.F. Dollfus, J.C.B Cotter and J.P. Gomes). Commission du Service Géologique du Portugal, 1903-04, Lisbonne, 1-44.

Dawson, S.D., 1996a. A new kentriodontid dolphin (Cetacea; Delphinoidea) from the Middle Miocene Choptank Formation, Maryland. Journal of Vertebrate Paleontology, 16, 135-140.

Dawson, S.D., 1996b. A description of the skull and postcrania of Hadrodelphis calvertense Kellogg 1966, and its position within the Kentriodontidae (Cetacea; Delphinoidea). Journal of Vertebrate Paleontology, 16, 125-134.

Eastman, C.R., 1907. Types of fossil cetaceans in the Museum of Comparative Zoology. Bulletin of the Museum of Comparative Zoology, 51, 79-94.

Estevens, M., 1998. Mamíferos marinhos do Neogénico de Portugal. Distribuição geográfica e estratigráfica. Comunicações do Instituto Geológico e Mineiro, 84, A161-A164.

Estevens, M., 2000. Miocene marine mammals from Portugal. Paleogeographical and paleoecological significance. Ciências da Terra (UNL), 14, 323-334.

Estevens, M. and Antunes, M.T., 2002. Fragmentary remains of odontocetes (Cetacea, Mammalia) from the Miocene of the Lower Tagus Basin (Portugal). In: Libro de resúmenes. XVIII Jornadas de la Sociedad Española de Paleontología / II Congreso Ibérico de Paleontología (Eds. J. Civis and J.A. González Delgado). Universidad de Salamanca, Salamanca, 190-191.

Fordyce, R.E., 1983. Rhabdosteid dolphins (Mammalia: Cetacea) from the Middle Miocene, Lake Frome area, South Australia. Alcheringa, 7, 24-40.

Gottfried, M., Bohaska, D.J. and Whitmore, F.C., Jr., 1994. Miocene Cetaceans of the Chesapeake Group. In: Contributions in Marine Mammal Paleontology Honoring Frank C. Whitmore, Jr. (Eds. A. Berta and T.A. Deméré). Proceedings of the San Diego Society of Natural History, 29, 229-238.

Hirota, K. and Barnes, L.G., 1994. A new species of Middle Miocene sperm whale of the genus Scaldicetus (Cetacea; Physeteridae) from Shiga-mura, Japan. The Island Arc, 3, 453-472.

Hulbert, R.C., Jr., Morgan, G.S. and Pratt, A.E., 2001. Whales and dolphins. In: The Fossil Vertebrates of Florida. (Ed. R.C. Hulbert, Jr.). University Press of Florida, Gainesvi1le, 331-342.

Ichishima, H., Barnes, L.G., Fordyce, R.E., Kimura, M. and Bohaska, D., 1994. A review of kentriodontine dolphins (Cetacea; Delphinoidea; Kentriodontidae): systematics and biogeography. The Island Arc, 3, 486-492.

Kazár, E., 2002. Revised phylogeny of the Physeteridae (Mammalia: Cetacea) in the light of Placoziphius Van Beneden, 1869 and Aulophyseter Kellogg, 1927. Bulletin de l'Institut Royal des Sciences Naturelles de Belgique, Sciences de la Terre, 72, 151-170.

Kellogg, R., 1925. On the occurrence of remains of fossil 
porpoises of the genus Eurhinodelphis in North America. Proceedings of the United States National Museum, 66, $1-40$.

Kellogg, R., 1955. Three Miocene porpoises from the Calvert cliffs, Maryland. Proceedings of the United States National Museum, 105, 101-154.

Menesini, E. and Tavani, G., 1968. Resti di Scaldicetus (Cetacea) nel Miocene della Puglia. Bollettino della Società Paleontologica Italiana, 7, 87-93.

Morgan, G.S., 1994. Miocene and Pliocene marine mammal faunas from the Bone Valley Formation of central Florida. In: Contributions in Marine Mammal Paleontology Honoring Frank C. Whitmore, Jr. (Eds. A. Berta and T.A. Deméré). Proceedings of the San Diego Society of Natural History, 29, 239-268.

Muizon, C. de, 1984. Les Vertébrés fossiles de la Formation Pisco (Pérou). Deuxième partie: Les Odontocètes (Cetacea, Mammalia) du Pliocène inférieur de Sud-Sacaco. Institut Français d'Études Andines, Mémoire 50, 1-188.

Muizon, C. de, 1987. The affinities of Notocetus vanbenedeni, an Early Miocene platanistoid (Cetacea, Mammalia) from Patagonia, Southern Argentina. American $\mathrm{Mu}$ seum Novitates, 2904, 1-27.
Muizon, C. de, 1988a. Le polyphylétisme des Acrodelphidae, Odontocètes longirostres du Miocène européen. Bulletin du Muséum National d'Histoire Naturelle, Paris, $4^{\mathrm{e}}$ série, section C, 10, 31-88.

Muizon, C. de, 1988b. Les Vertébrés fossiles de la Formation Pisco (Pérou). Troisième partie: Les Odontocètes (Cetacea, Mammalia) du Miocène. Institut Français d'Études Andines, Mémoire 78, 1-244.

Muizon, C. de, 1991. A new Ziphiidae (Cetacea) from the Early Miocene of Washington State (USA) and phylogenetic analyses of the major groups of odontocetes. Bulletin du Muséum National d'Histoire Naturelle, Paris, $4^{\mathrm{e}}$ série, section C, 12, 279-326.

Myrick, A.C., Jr., 1979. Variation, taphonomy and adaptation of the Rhabdosteidae (=Eurhinodelphidae) $($ Odontoceti, Mammalia) from the Calvert Formation of Maryland and Virginia. Ph.D., University of California, Los Angeles, 437 pp.

Okazaki, Y., 1976. Miocene long-snouted porpoises from the Mizunami Group, Central Japan. Bulletin of the Mizunami Fossil Museum, 3, 25-39.

Varola, A., Landini, W. and Pilleri, G., 1988. A new Scaldicetus (Cetacea: Physeteridae) from the Pietra Leccese, Late Miocene. Investigations on Cetacea, 21, 16-38.

Manuscrito recibido: 19 de diciembre, 2002 Manuscrito aceptado: 14 de noviembre, 2003 